\title{
Investigation of the effect of SiC content on the microstructure, physical properties and hardness of $\mathrm{SiC} / \mathrm{Ni}$ composites
}

\author{
Hanan M. Makled ${ }^{1}$, Mahmudun N. Chowdhury ${ }^{2}$, \\ Ahmed I. Ali ${ }^{\dot{3}, 4}$, Ibrahim S.Qassem ${ }^{5}$, Walid M. Daoush ${ }^{1,6}$ \\ ${ }^{1}$ Department of Production Technology, Faculty of Industrial Education, \\ Helwan University, Saray-El Qoupa, El Sawah Street, 11281 Cairo, Egypt \\ ${ }^{2}$ RMIT Centre for Additive Manufacturing, RMIT University, \\ 3000 Melbourne, Australia \\ ${ }^{3}$ Basic Science Department, Faculty of Industrial Education, Helwan \\ University, Saray-El Qoupa, El Sawah Street, 11281 Cairo, Egypt \\ ${ }^{4}$ Nanotechnology Research Center, The British University in Egypt, El \\ Sherouk City, Suez Desert Road, 11837 Cairo, Egypt \\ ${ }^{5}$ Curricula and Teaching Methods Department, Faculty of Education, \\ Helwan University, Cairo, Egypt \\ ${ }^{6}$ Department of Chemistry, college of Science, Imam Mohammad ibn Saud \\ Islamic University (IMSIU), Riyadh, KSA
}

Received November 21, 2018

\begin{abstract}
Nickel matrix composites reinforced with alpha-silicon carbide of various concentrations (up to 4 wt.\%) were investigated. Samples were made by powder mixing followed by a process of powder technology. The resulting $\mathrm{SiC} /$ nickel composite powders were cold compacted at $400 \mathrm{MPa}$ in a single-axis head, followed by sintering in a controlled furnace at $1000^{\circ} \mathrm{C}$ in an atmosphere of sintering a hydrogen/nitrogen mixture of $3: 2$. The $\mathrm{SiC} / \mathrm{Ni}$ powders, as well as crushed and polished consolidated composites were investigated using a scanning electron microscope and X-ray diffraction (XRD). The microstructures of the obtained sintered $\mathrm{SiC} / \mathrm{Ni}$ composites show a uniform distribution of SiC particles in the nickel matrix. XRD data showed that the sintered SiC/Ni composites consist mainly of (fcc) $\mathrm{Ni}$ as the main phase and $\alpha-\mathrm{SiC}$ phase. To assess the sintering process of the obtained $\mathrm{SiC} / \mathrm{Ni}$ composites, their density, electrical conductivity, coefficient of thermal expansion at various temperatures, and hardness were measured. The relative density, electrical conductivity, and thermal expansion coefficient of the sintered SiC/Ni composites obtained decreased; hardness increased by increasing the SiC content in the nickel matrix.

Keywords: $\mathrm{SiC} / \mathrm{Ni}$ composites, sintering, coefficient of thermal expansion, electrical conductivity, hardness.

Исследованы никелевые матричные композиты, армированные альфа-карбидом кремния различных концентраций (до 4 мас. \%). Образцы изготавливались методом смешивания порошков с последующим процессом порошковой технологии. Полученные композиционные порошки $\mathrm{SiC} / \mathrm{Ni}$ подвергались холодному прессованию при 400 МПа в одноосной головке с последующим спеканием при $1000^{\circ} \mathrm{C}$ в атмосфере водород/азот (3:2). Порошки $\mathrm{SiC} / \mathrm{Ni}$ и измельченные, отполированные консолидированные композиты исследованы методами сканирующей электронной микроскопии и рентгеноструктурного анализа. Микроструктуры композитов $\mathrm{SiC} / \mathrm{Ni}$, полученных после спекания, харак-
\end{abstract}


теризуются однородным распределением частиц SiC в никелевой матрице. Данные рентгеноструктурного анализа показали, что спеченные композиты $\mathrm{SiC} / \mathrm{Ni}$ состоят в основном из (ГЦК) $\mathrm{Ni}$ в качестве основной фазы и фазы $\alpha-\mathrm{SiC}$. Для оценки влияния процесса спекания на полученные композиты $\mathrm{SiC} / \mathrm{Ni}$ измерены их плотность, электропроводность, коэффициент теплового расширения при различных температурах и твердость. Относительная плотность, әлектропроводность и коэффициент теплового расширения композитов $\mathrm{SiC} / \mathrm{Ni}$ снижаются в процессе спекания, тогда как твердость увеличивается за счет увеличения содержания SiC в никелевой матрице.

Дослідження впливу вмісту SiC на мікроструктуру, фізичні властивості і твердість композитів SiC/Ni. Hanan M. Makled, Mahmudun N. Chowdhury, Ahmed I. Ali, Ibrahim S. Qassem, Walid M. Daoush.

Досліджено нікелеві матричні композити, армовані альфа-карбідом кремнію різних концентрацій (до 4 мас.\%). Зразки виготовлялися методом змішування порошків 3 подальшим процесом порошкової технології. Отримані композиційні порошки $\mathrm{SiC} / \mathrm{Ni}$ піддавали холодному ущільненню при 400 МПа в одноосній голівці з наступним спіканням при $1000^{\circ} \mathrm{C}$ в атмосфері водень/азот (3:2). Порошки $\mathrm{SiC} / \mathrm{Ni}$ і подрібнені, відполіровані консолідовані композити досліджено за допомогою методів скануючої електронної мікроскопії та рентгеноструктурного аналізу. Мікроструктури композитів $\mathrm{SiC} / \mathrm{Ni}$, отриманих після спікання, характеризуються однорідним розподілом часток у нікелевій матриці. Дані рентгеноструктурного аналізу показали, що спечені композити $\mathrm{Sc} / \mathrm{Ni}$ складаються в основному з (ГЦК) в якості основної фази і фази $\alpha-\mathrm{SiC}$. Для оцінки впливу процесу спікання на отримані $\mathrm{SiC} / \mathrm{Ni}$ композити виміряно їх густину, електропровідність, коефіцієнт теплового розширення при різних температурах $\mathrm{i}$ твердість. Відносна густина, електропровідність і коефіцієнт теплового розширення композитів $\mathrm{SiC} / \mathrm{Ni}$ знижуються у процесі спікання, тоді як твердість збільшується за рахунок збільшення вмісту $\mathrm{SiC}$ у нікелевій матриці.

\section{Introduction}

Nowadays, different types of materials can be used in the fabrication of cutting tools in metal working industry, including high carbon steel, hard metals and alloys, ceramics, cubic boron nitride, diamonds, cermets and composites etc. In most cases the tool is based on the proper material for each application. Because of the good mechanical properties of ceramic cutting tools, the high-speed machining is used in the machining industry [1-6]. Therefore, the physical and mechanical properties of cutting tools play an important rule to ensure the efficiency of machining. Ceramic cutting tool are the most important for machining hard materials due to their excellent mechanical properties at elevated temperatures [7, 8]. SiC cutting tools which became the promising cutting tools among the ceramic cutting tools due to their high hardness [2, 3], strength, and fracture toughness [9-11]. However, the limitations of their applications are insufficient wear resistance and inferior thermal shock resistance, which causes high wear rate $[10,11]$. To obtain a good wear resistance cutting tools, a SiC cutting tools was introduced in the light spot for researchers in the last three decades on a wide variety of applications $[13,14]$. Due to their high thermal conductivity, high fracture toughness, high wear resistance, and stabilities at elevated temperatures, SiC ceramic cutting tools can show reliable cutting performance during high speed turning of gray cast iron [1518]. However, SiC cutting tools faces many problems during the machining such as high temperature of edge, high temperature of the cutting tools, and weak resistance with high speeds; resulting in the weakness of the industrial production [19-22]. Recently, the composites are widely used in fabrication of cutting tools due to their excellent properties at high temperature and resistance of corrosions [23]. Ni composite reinforced with ceramic particles are considered as the suitable candidate for the application of cutting tools because of his chemical stability at elevated temperatures, thermal coefficient expansion, hardness, resistance of corrosion [22-27]. Ni embedded with SiC was studied for the application in the fabrication of cutting tools [21]. The addition of $\mathrm{Ni}$ to $\mathrm{SiC}$ composites had improved the physical and mechanical properties of cutting tools. It was reported in previous work that, the interfacial reactions between $\mathrm{Ni}$ and $\mathrm{SiC}$ have been improved its properties $[23,25]$. The SiC/Ni composite increased the strength properties of cutting tools at elevated temperature and high pressure. In addition, $\mathrm{Ni}$ is enhanced the thermal and electric conductivity [22]. 


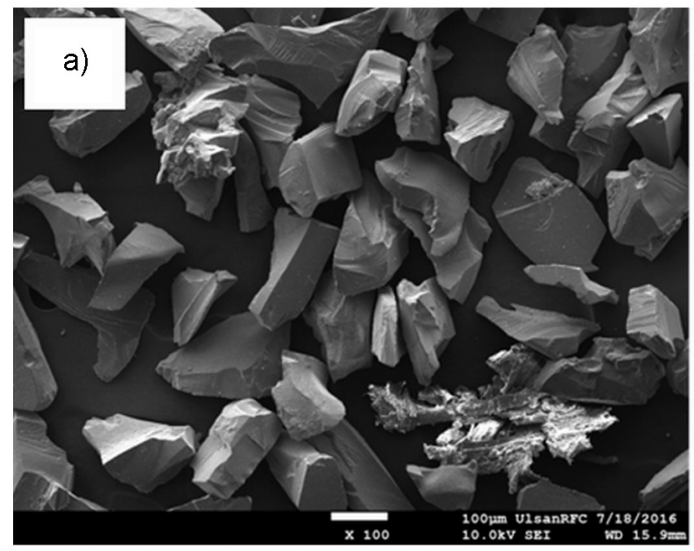

Fig. 1. SEM images of a) $\mathrm{SiC}$ and b) Ni powders.

The presence work deals with the study of the effect of SiC content on the microstructure and properties of SiC/Nickel composites fabricated by using powder metallurgy technique. The produced sintered composites were investigated using XRD and SEM. The conductivity at room temperature, thermal expansion coefficient at different temperatures as well as the hardness have been measured to evaluate the produced sintered composites.

\section{Experimental}

$\alpha-$ SiC powder with an average particle size of $100 \mu \mathrm{m}$ were provided from Bohler Co LTD, Germany, powder with a specific particle size of $2-3 \mathrm{~mm}$ was purchased from Jin Sheng International Industrial LTD (China), paraffin wax was purchased from El-Nas ser Co LTD (Egypt), acetone was provided from El-Nasser Co LTD (Egypt).

Fig. 1 shows SEM images of the investigated $\alpha-\mathrm{SiC}$ and $\mathrm{Ni}$ powders. It is observed that, the SiC particles have equiaxed particle shape however, the $\mathrm{Ni}$ particles have polygonal particle shape.

Six groups of $\mathrm{SiC} / \mathrm{Ni}$ mixtures are prepared (Ni pure, Ni/wax, 1, 2, 3 and 4 wt.\% $\mathrm{SiC}$ and the balance is $\mathrm{Ni}$ ). The sample mixtures are prepared by grinding of the constituents in agate mortar for 30 min using acetone as a grinding media. The obtained mixtures were cold compacted at $400 \mathrm{MPa}$ in a uniaxial die with diameter of $12 \mathrm{~mm}$ using a hydraulic press. The compacted samples are then sintered at $1000^{\circ} \mathrm{C}$ under controlled atmosphere of $\left(3: 2 \quad \mathrm{H}_{2} / \mathrm{N}_{2}\right.$ gas mixtures) for $120 \mathrm{~min}$. The produced intered samples are grinded, polished and underwent metallographic investigations by SEM.

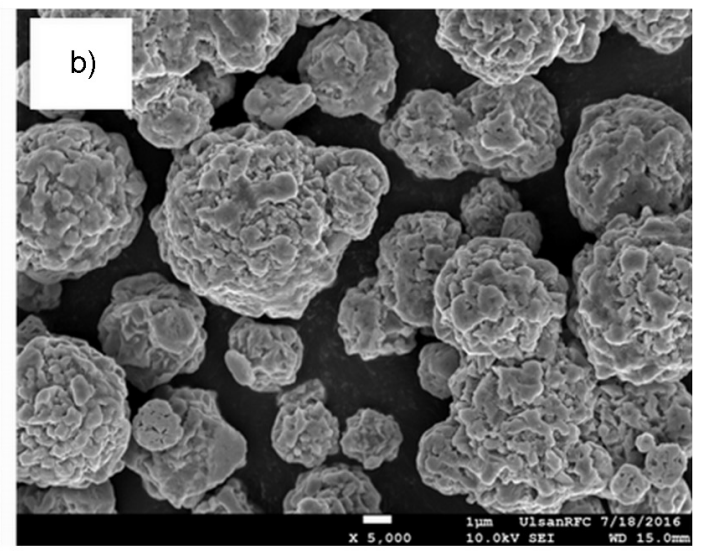

The theoretical densities of the produced composites were calculated by using the rule of mixtures using Eq. (1):

$$
d_{c}=d_{m} \cdot V_{m}+d_{f} \cdot V_{f},
$$

where $d_{c}, d_{m}, d_{f}$ are the densities of the composite, $\mathrm{Ni}$ matrix and $\mathrm{SiC}$ reinforcement phase, respectively and $V_{m}, V_{f}$ are the fractional volume of the Ni matrix and SiC phase, respectively.

The density of the obtained $\mathrm{SiC} / \mathrm{Ni}$ sintered samples was measured using water as a floating liquid and the sintered density $\rho$ is calculated by the Archimedes principal using Eq. (2) as follows;

$$
\rho=W_{\text {air }} / W_{\text {air }}-W_{\text {water }},
$$

where $W_{\text {air }}$ and $W_{\text {water }}$ are the weight of specimen in air and in water, respectively. The relative density $\rho_{\text {relative }}$ is estimated by calculating the ratio of the actual composite density $\rho$ to the theoretical density $\rho_{t h}$ by using Eq. (3) as follows;

$$
\rho_{\text {relative }}=\rho_{r} / \rho_{t h} \text {. }
$$

The coefficient of thermal expansion is measured using the dilatometry method at 50, $100,150,200,250$ and $300^{\circ} \mathrm{C}$, respectively, for $15 \mathrm{~min}$ by heating rate of $17^{\circ} \mathrm{C} / \mathrm{min}$. The linear coefficient of thermal expansion (CTE) was calculated according to the Eq. (4):

$$
\alpha=\frac{1}{\Delta T} \varepsilon=\left(\frac{1}{L_{0}}\right) \frac{\Delta L}{\Delta T},
$$

where $\alpha$ is the CTE, $\Delta T=T-T_{0}$ is the temperature interval, and $T_{0}=293 \mathrm{~K}, \varepsilon=\Delta L / L_{0}$ is the relative length in the change, and $\Delta L$ is the expansion $\left(\Delta L=L-L_{0}\right)$ and $L_{0}$ is the original length. 
The theoretical electrical conductivity of the produced $\mathrm{SiC} / \mathrm{Ni}$ composites is calculated by using the rule of mixtures by using Eq. (5) as follows:

$$
E_{c}=P_{m} \cdot V_{m}+P_{f} \cdot V_{f},
$$

where $P_{m}, P_{f}$ are the theoretical conductivity of the metal and the reinforcement phase, respectively and $V_{m}, V_{f}$ are the fractional volume of the metal matrix and reinforcement phase, respectively.

The electrical resistivity of the SiC/Ni composites is measured by the four-probe method using a digital Multi-meter GDM6145 device. The resistivity $\rho$ is determined using Eq. (6), while the electrical conductivity $\sigma$ is calculated by applying the data of the resistivity in the Ohm's law as follows:

$$
\rho=R \cdot A / L,
$$

where $R$ is the resistance in $\mu \Omega, L$ is the length measured in $\mathrm{cm}, A$ is the cross-section area in $\mathrm{cm}^{2}, \rho$ is the resistivity in $\mu \Omega \mathrm{cm}$ and the electrical conductivity $\sigma$ is the reciprocal of the electrical resistivity $\sigma=1 / \rho$.

The micro-hardness values of the present $\mathrm{SiC} / \mathrm{Ni}$ composites are measured by taking the average of six different indentation measurements on each specimen using 100gram load for $15 \mathrm{sec}$.

\section{Results and discussion}

Powder compaction has assumed an important role in the production of many powder metallurgy products. It is a complex phenomenon consisting of a continuous decrease in porosity by progressive compaction. Different identifiable stages occur during powder compaction, namely, sliding and rearrangement of the particles, elastic compression at the particle-particle contact points and plastic deformation at these contact points, or fragmentation for brittle materials. These stages overlap to a certain degree and are influenced with the characteristics of powders in terms of: strength, size, size distribution and shape, and also the method of compaction. Sintering is the most important and, from the technical viewpoint, the most difficult procedure in production of sintered materials. As a result of this operation, the material acquires the required physical and mechanical properties. Sintering is the final operation in the manufacture of powder metallurgy parts. Sintering is often carried out in a controlled atmosphere which enables the required properties of sintered material to be obtained without oxidation or other reactions, depending on the nature of material in furnace with either a protective atmosphere or in vacuum furnace. Sintering process changes a dispersed or powdered body into a solid metallic one.

In this investigation, the sintering process was assessed by measuring the change in dimensions of each sample manually before and after sintering using a dial gauge micrometer of $10^{-3} \mathrm{~mm}$ sensitivity. The change in dimensions and weights of investigated materials during sintering is the result of changes in dimensions and weights of $\mathrm{SiC} / \mathrm{Ni}$ composites which were mixed previously. In order to understand the effect of the SiC content on the changes in the dimension of the investigated materials, the sinterability of the sintered materials were measured. It was found that almost no changes in weight of the produced $\mathrm{SiC} / \mathrm{Ni}$ composites were observed during sintering operation, which meant that no reaction between the constituents ( $\mathrm{SiC}$ and $\mathrm{Ni}$ ) and the hydrogen or nitrogen gas was taking place during sintering for all the produced samples.

Fig. 2(a-d) shows SEM micrographs of the cross-sectional area of the prepared 1 , 2, 3 and 4 wt.\% SiC/Ni sintered composites. It is observed that, the SiC particles are homogenously distributed in the nickel matrix with good adhesion between $\mathrm{SiC}$ and Ni-matrix. As one can notice that in the micrograph (a) of 1 wt.\% of $\mathrm{SiC}$ in $\mathrm{Ni}$ matrix, equiaxed $\mathrm{SiC}$ particles is dispersed in the nickel matrix which as black particles in the $\mathrm{Ni}$ matrix. By increasing the SiC wt. \% the dispersed phase volume content is increased as shown in the microstructures of the produced composites. It also observed from the microstructure of the produced $\mathrm{SiC} / \mathrm{Ni}$ sintered composites that some pores are appeared in the nickel matrix. This porosity content is due to the partial coalescence of some nickel particles during sintering at $1000^{\circ} \mathrm{C}$ temperature. This low sintering temperature was selected to be below the oxidation temperature of silicon carbide and nickel and to keep the structure and the chemical composition of silicon carbide and nickel stable under the sintering conditions in the presence of the inert (non-oxidizing) atmosphere of $\mathrm{H}_{2} / \mathrm{N}_{2}$ gases. The reason for the improved bonding sinterability and density of $\mathrm{SiC} / \mathrm{Ni}$ composites is mainly due to the particle/particle contacts are mainly $\mathrm{Ni} / \mathrm{Ni}$ contacts and sintering behaves like $\mathrm{Ni}$ com- 


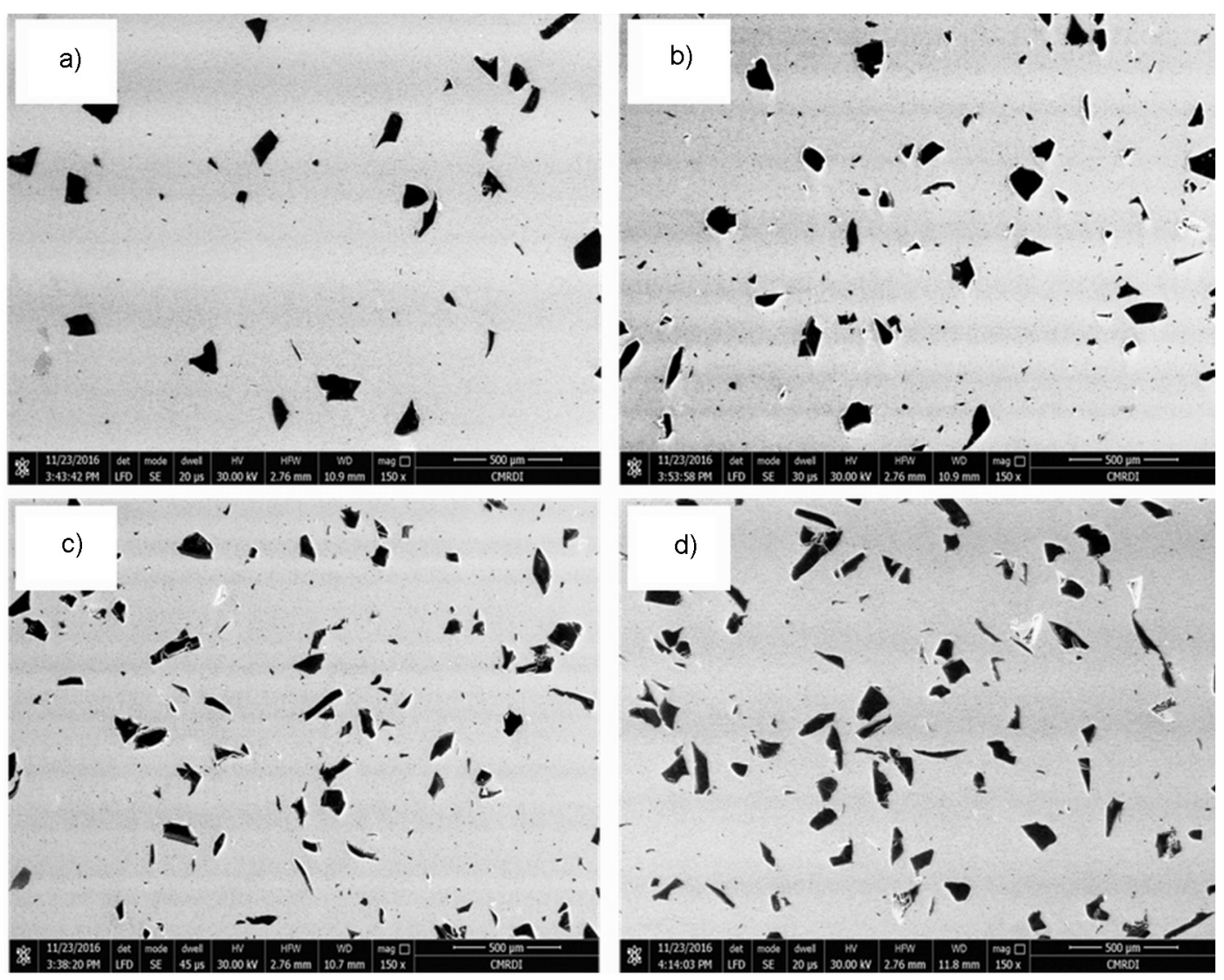

Fig. 2. SEM micrographs of $\mathrm{SiC} / \mathrm{Ni}$ composites where; a) 1 wt. $\% \mathrm{SiC} / \mathrm{Ni}$, b) 2 wt. \% $\mathrm{SiC} / \mathrm{Ni}$, c) 3 wt. $\% \mathrm{SiC} / \mathrm{Ni}$ and d) 4 wt. \% SiC/Ni composites.

pacts sintering especially in case of low $\mathrm{SiC}$ content in the obtained $\mathrm{SiC} / \mathrm{Ni}$ composites.

The X-ray diffraction patterns of the produced sintered $\mathrm{Ni}$ and it corresponding $\mathrm{SiC} / \mathrm{Ni}$ composites sintered at $1000^{\circ} \mathrm{C}$ are shown in Fig. 3. It is observed that, the identical peaks of pure nickel and SiC phases were appeared. It also showed from the result that, the sintered $\mathrm{SiC} / \mathrm{Ni}$ composites consists of (fcc) $\mathrm{Ni}$ as a major phase and a coexisting $\alpha-S i C$ is appeared. It was found that there is no foreign peak are appeared indicating that there are no any foreign inclusions impeded in the samples. Although the $\mathrm{Ni}$ metal and the $\mathrm{SiC}$ can react under elevated temperature, the investigated sintering temperature $\left(1000^{\circ} \mathrm{C}\right)$ and the short sintering time $(120 \mathrm{~min})$ are not suitable conditions to enhance the interaction between $\mathrm{Ni}$ and the particles under the controlled atmosphere of $\left(\mathrm{H}_{2} / \mathrm{N}_{2}\right.$ gas mixtures). In addition, the XRD diffraction pattern of pure $\mathrm{Ni}$ metal shows diffraction peaks of (311), (220) and (111) characteristics of a (fcc) structure. The XRD diffraction pattern of the $\mathrm{SiC} / \mathrm{Ni}$ composites reflected no changes in the microstructure. This result indicated that the produced $\mathrm{SiC} / \mathrm{Ni}$ composites does not oxidized and chemically stable during the sintering process at $1000^{\circ} \mathrm{C}$ under the controlled reduced atmosphere of $\left(3: 2 \mathrm{H}_{2} / \mathrm{N}_{2}\right.$ gas mixtures) for $120 \mathrm{~min}$. By other word the sintering temperature is lower than the oxidation temperatures of both the $\mathrm{Ni}$ metal and the $\alpha-\mathrm{SiC}$ particles.

Fig. 4 shows the relative sintered densities in comparison with the corresponding relative green densities of the produced $\mathrm{SiC} / \mathrm{Ni}$ composites with different SiC content. The relative green densities of the produced $\mathrm{SiC} / \mathrm{Ni}$ green composites were determined by calculating the engineering densities. The weight of each sample was measured using three-digit electric balance and its dimension and volume was calculated using $0.01 \mathrm{~mm}$ micrometer. It is observed that the composites of low SiC content has higher relative densities than the composites have higher SiC contents. It is due to the good sinterability of composites have low SiC content which enhance the formation of strong binding forces between the 


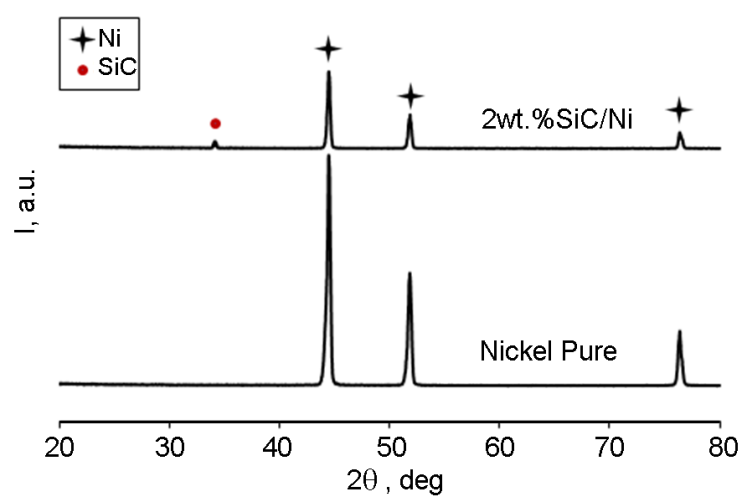

Fig. 3. XRD patterns of pure nickel and the corresponding $\mathrm{SiC} / \mathrm{Ni}$ composite.

SiC particles and the nickel matrix. However, by increasing the SiC content the sinterability is decreased due to the crowding and agglomerations of the SiC particles in the $\mathrm{Ni}$ matrix which enhance the particleparticle interactions and the formation of air gaps between the SiC particles and the $\mathrm{Ni}$ matrix and form weak binding forces between the SiC particles and the $\mathrm{Ni}$ matrix.

Fig. 5 shows the effect of temperature on the coefficient of thermal expansion (CTE) of the prepared $\mathrm{SiC} / \mathrm{Ni}$ composites. It was noted that the CTE decreased by increasing of the SiC content. Also, the results observed that, the slope of the CTE line increased linearly up to $300^{\circ} \mathrm{C}$. This is due to the initial hydrostatic compression of the reinforcement is relieved partially through the Ni-matrix causing an increasing expansion of the composite by raising the temperature. It also observed that at high temperature above $200^{\circ} \mathrm{C}$, the CTE values increased by smaller rates than at low temperature below $200^{\circ} \mathrm{C}$, because the internal stresses in the matrix are decreased during heating due to the decreasing mismatch strains and their more uniform redistribution by relaxation processes, namely plastic flow at high temperature [15-17].

The conductivity measurements were performed in order to investigate the effect of SiC content on the sinterability of the $\mathrm{SiC} / \mathrm{Ni}$ composites. Fig. 6 shows the electrical conductivity values of the produced $\mathrm{SiC} / \mathrm{Ni}$ composites as a function of the SiC content. It was observed that by increasing the $\mathrm{SiC}$ content in the $\mathrm{Ni}$ matrix, the electrical conductivity decreased. It is due to two factors, first is the electrical property of metals originally is influenced by the electron movement in the composite structure and decrease the conductivity of the $\mathrm{Ni}$ ma-

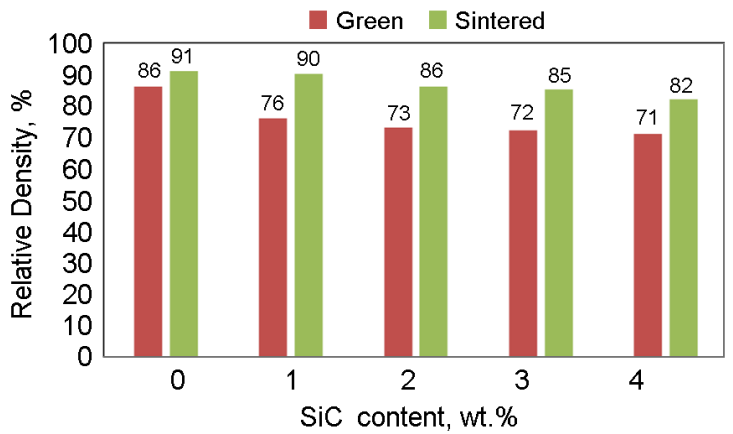

Fig. 4. Effect of SiC content on the relative green and sintered density of the produced $\mathrm{SiC} / \mathrm{Ni}$ composites.

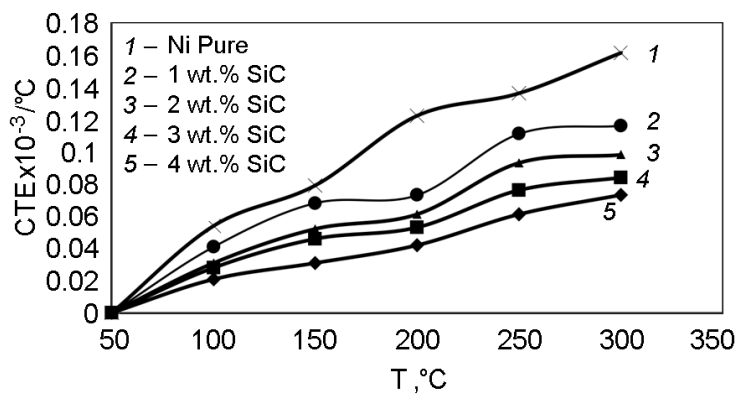

Fig. 5. Effect of SiC content on the CTE at different temperatures of the produced $\mathrm{SiC} / \mathrm{Ni}$ composites.

trix. By increasing of the $\mathrm{SiC}$ content in the metal matrix, the structure distorts due to the formation of the interfaces between the SiC particles and the nickel matrix causes some impediment for the electron motion. This leads to increase in resistivity and consequently decrease electrical conductivities of the composites with increasing the SiC particles content. The second reason is the contribution of the SiC particles as poor conductor decrease the total electrical conductivity of the composite. In addition, the electrical conductivity is directly affected by porosity, the greater the void content, the lower is the electrical conductivity. Since the conductivity of a pore is zero. The increase of resistivity is largely attributable to the formation of excess vacancies. Porosity caused a break in the continuous Ni-matrix skeleton network, which is responsible for conducting electrical current in the composite materials. The absence of this continuous network increases the electrical resistivity [28].

Hardness measurements were performed in order to investigate the strengthening effect of SiC particles reinforcements on the $\mathrm{Ni}$ matrix. The Vickers hardness values of $\mathrm{SiC} / \mathrm{Ni}$ composites are shown in Fig. 7. In general, it was observed that, by increasing the $\alpha$-SiC-hard phase content, an increasing 


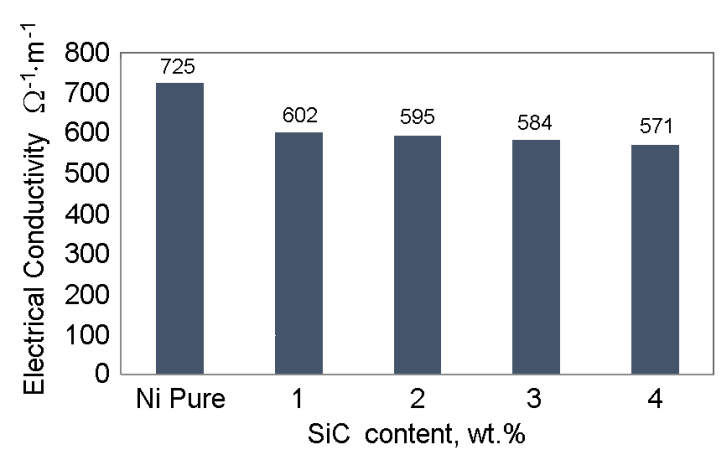

Fig. 6. Effect of SiC content on the electrical conductivity of the prepared $\mathrm{SiC} / \mathrm{Ni}$.

in the hardness of specimens exhibited. This is expected because the hardness of $\alpha-S i C$ is higher than the hardness of $\mathrm{Ni}$. The in-situ hardness of $\mathrm{Ni}$, namely 66 , is much lower than the typical values of 240 for bulk Ni. This difference is explained due to the effect of the porosity content $(\sim 9 \%$.) in the $\mathrm{Ni}$ matrix as shown in Fig. 4. This result can be discussed due to the densification effect. By increasing the $\mathrm{Ni}$ metal binder content $(\alpha-S i C$-particles content decreased), the porosity was decreased, the densification was increased and as a result the hardness increased. On the other hand, by increasing the content of $\alpha-S i C$-reinforcement phase, the hard phase increased and enhanced the total hardness of the $\mathrm{SiC} / \mathrm{Ni}$ composite. One can also shows from the data of the measured hardness for the $\mathrm{Ni}$ binder phase that the exact character of the microstructure as shown in Fig. 2 has a critical influence on the hardness. There is no evidence of a continuous $\alpha-S i C$-skeleton in the materials. The low surface energies that correspond to such complete wetting promote coverage of all the $\mathrm{SiC}$ particles surface with $\mathrm{Ni}$ matrix $[29,30]$.

\section{Conclusions}

In this work, $\alpha-\mathrm{SiC} / \mathrm{Ni}$ composite powder mixtures with different $\alpha-S i C$-content were prepared. The $\mathrm{SiC} / \mathrm{Ni}$ composite powders were consolidated using conventional powder technology route with a 120 min holding time, the composites could be consolidated to full density at relatively low temperature of $1000^{\circ} \mathrm{C}$. The microstructure characterizations of the obtained $\mathrm{SiC} / \mathrm{Ni}$ composites showed that the SiC particles were embedded in the $\mathrm{Ni}$ matrix exerted strong influence on the properties of the produced composites. The X-ray diffraction of the produced composites identifies two

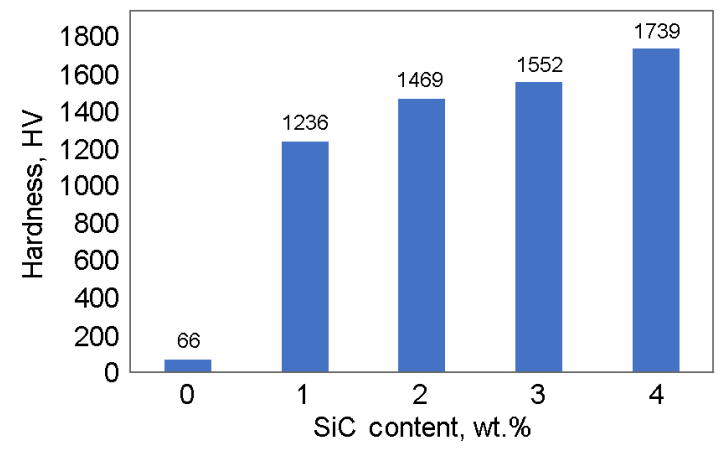

Fig. 7. The effect of SiC addition on the hardness of the produced $\mathrm{SiC} / \mathrm{Ni}$ composites.

single different phases, one for $\mathrm{SiC}$ and the other for Ni. Significant decrease in the sintering density as well as the electrical conductivity of the produced $\mathrm{SiC} / \mathrm{Ni}$ composites could be observed. The coefficient of thermal expansion at different temperatures of the produced composites decreases by increasing content. The hardness of $\mathrm{SiC} / \mathrm{Ni}$ composites increases by increasing the $\mathrm{SiC}$ content. These changes were reflected in an increase of the hardness as compared to pure $\mathrm{Ni}$. By increasing the $\mathrm{SiC}$ content, the density is clearly decreases while the strengthening is progressively achieved. From our results, we suggested that the particles can be reinforced in the $\mathrm{Ni}$ matrix and improved the properties of $\mathrm{Ni}$, which make it great candidate as a cutting tool.

Acknowledgment. The authors would like to thank, Mr. Moustafa El Sokary, Mr.Ahmed Swedan, Mr. Mahmoud Ahmed, Mr. Ahmed El-Tantawy, the technician staff at the faculty of industrial education in Helwan University and the XRD and SEM technicians at the Central Metallurgical R\&D Institute in Cairo for their cooperation.

\section{References}

1. X.Ai, Technology of High-Speed Cutting, 1st ed. National Defense Industry Press, Beijing (2003).

2. Y.Long, J.Zeng, D.Yu, Ceram.Int., 40, 9889 (2014).

3. Y.Long, J,Zeng, S.Wu, Ceram.Int., 40, 9615 (2014).

4. A.El-Tantawy, W.Daoush, A.El-Nikhaily, J.Exp. Nanoscience, 13, 174 (2018).

5. H.Yehia, W.Daoush, A.El-Nikhaily, Powder Metallurgy Progr., 15, 262 (2015).

6. W.Daoush, H.Park, S.Hong, Trans. Nonferrous Met.Soc.China, 24, 3562 (2014).

7. P.K.Mehrotra, Key Eng. Mater., 138-140, 1 (1998).

8. J.Qin, Y.Long, J.Zeng, Ceram.Int., 40, 12245 (2014). 
9. J.Gubicza, P.Arato, F.Weber, Mater.Sci.Eng. $A, \mathbf{2 5 9}, 65$ (1999).

10. R.P.Martinho, F.J.G.Silva, A.P.M.Baptista, Wear, 263, 1417 (2007).

11. J.W.C.Souza, M.C.A.Nono, M.V.Ribeiro, Mater. Des., 30, 2715 (2009).

12. W.Grzesik, J.Malecka, Manuf.Technol., 60, 121 (2011).

13. C.Tian, H.Jiang, N.Liu, Int.J.Refract.Met. Hard Mater., 29, 14 (2011).

14. T.Ekstrom, M.Nygren, J.Am.Ceram.Soc., 75, 259 (1992).

15. V.A.Izhevskiy, L.A.Genova, J.C.Bressiani, J. Eur.Ceram.Soc., 20, 2275 (2000).

16. S.Kurama, I.Schulz, M.Herrmann, J.Eur. Ceram.Soc., 31, 921 (2011).

17. C.Roberto, da M.Silva, Mater.Sci.Eng.A, 209, 175 (1996).

18. C.Yamagishi, J.Hakoshima, S.Nakajo, $A d v$. Mater., 93, 919 (1994).

19. Li Dan, B.J.Hai, S.C.Moa et al., J.Am.Ceram. Soc., 94, 1523 (2011).
20. M.Fanbing, W.Bo, F.G.Fang, H.Feng, Surface Coatings Techn., 213, 77 (2012).

21. Y.H.Sang, L.L.Jong, J.Electrochem.Soc., 149, 189 (2002).

22. G.Z.Zou, M.S.Cao, H.B.Lin et al., J.Powder Technol., 168, 84 (2006).

23. C.H.Xu, G.Y.Wu, G.C.Xiao, B.Fang, Int.J. Refract. Met. Hard Mater., 45, 125 (2014).

24. X.Ai, Z.Q.Li, J.X.Deng, Key Eng Mater, 108, 53 (1995).

25. A.Fissel, B.Schroter, W.Richte, Appl.Phys. Lett., 66, 3182 (1995).

26. W.Daoush, O.Elkady, J.Comp.Mater., 48(30), 3735 (2014).

27. C.H.Xu, Y.M.Feng, R.B.Zhang, J.Mater. Process. Technol., 209, 4633 (2009).

28. M.Ahmed, W.Daoush, A.El-Nikhaily, Adv.Mater. Res., 5, 131 (2016).

29. W.Daoush, H.Park, K.Lee et al., Inter.J.Ref. Met. Hard Mat., 27, 669 (2009).

30. W.Daoush, K.Lee, H.Park, S.Hong, Inter.J. Ref. Met. Hard Mat., 27, 83 (2009). 